\title{
Dairy production practices at pastoral settlements of Adamawa and Taraba states,
} Northeastern Nigeria

\author{
${ }^{1 *}$ Adamu, Z., ${ }^{2}$ Ardo, M. B. and ${ }^{3}$ Aliyara, Y. H.
}

Department of Animal Health, College of Agriculture, Jalingo
Department of Animal Science, Modibbo Adama University of Technology, Yola

Department of Animal Science, Taraba State University, Jalingo.

Abstract

A survey was undertaken to investigate the dairy production practices in pastoral communities in Adamawa and Taraba states using a well-structured questionnaire. A total of 600 pastoralists in 20 local government areas (LGAs) were used in this study. Data from the questionnaires were presented in simple percentages. The survey showed that dairy pastoralists was dominated by married middle aged men (82.0\%), low in literacy level (78.0\%), herding local breeds of cattle (97.0\%) that used rivers $(91.7 \%)$ around their settlements as source of water. Most of them sale raw milk once a day (98.2\%), with highest quantity during rainy season (98.3\%) which was mostly used in their families as food and sale remainder (81.5\%), but were willing to sale to milk collectors (62.5\%). The unavailability of extension agents to assist them improves their dairy practices $(89.2 \%)$ and non-membership of cooperative societies by pastoralists $(82.7 \%)$ were constraints to dairy production in pastoral settlements. However, majority of pastoralists are willing to join milk cooperative society (96.6\%) indicates the future development and commercialization of pastoralist milk industry is bright. Extension agents are required to enlighten on the good feeding regimens, marketing and cross breeding techniques. The result from this study indicated the need for government to exploit the potentials of improving the business and entrepreneurship skills of pastoralists through encouraging private entrepreneurs in dairy production.

Keywords: Adamawa state, Milk, milk collectors, Pastoralist, Taraba state

\section{Introduction}

Globally, pastoralism is characterized by keeping large herds of indigenous breeds (Magembe et al., 2010) by culture and economic orientation towards livestock. Pastoralism, a farming system involving mobility of people with their livestock in search of pastures and water is the major characteristic of rangelands. Livestock ownership currently supports or sustains the livelihoods of an estimated 700 million rural poor, approximately $70 \%$ of the world's rural poor population. The importance of the dairy cow is expected to increase as food imports to sub-Saharan Africa (SSA) are projected to more than double by 2030 under a business as usual scenario (The World Bank, 2008). In Nigeria, cattle provide more than $90 \%$ of the total animal milk output while goats and sheep provide less than $10 \%$ and are kept for production of meat, hides and skin (Walsche et al, 1991). The White Fulani breed popularly called 'Bunaji' is the most numerous and wide spread of all the Nigerian cattle breeds accounting for about $37 \%$ of the national cattle population (Oni et al, 2001). In spite of the existing enormous livestock resource and great potential for increased livestock production, the productivity is disproportionately lower due to various livestock management problems; prevalence of major endemic diseases; poor feeding; high stocking rate on grazing lands and low genetic potentials. Degradation of rangelands manifested by bush encroachment, gullies due to soil erosion and bare ground along the cattle paths and resting grounds, has greatly affected their 
carrying capacity and production potentials (Mpaire, 2001). Therefore, pastoralists keep animals as stores of wealth-in-kind and insurance scheme that ensure returns from the investment (David et al, 2001). As risk aversion strategy, pastoralists participate in the market primarily for convenience of adapting to inclement weather and disease incidences. However, the demand for milk and dairy products in developing countries is estimated to increase by $25 \%$ by 2025 (Delgado et al., 1999), mainly due to human population growth, further urbanization, increased disposable income, greater diversity of food products to meet nutritional needs, and increased opportunities for domestic and external trade. Indeed, dairy imports in developing countries may reach 38.9 billion litres of milk equivalent by 2030 (FAO/IDF, 2004). This study, therefore, was carried out to access the dairy production practices in pastoral settlements of Adamawa and Taraba states.

\section{Materials and methods Study areas}

Adamawa is a state in northeastern Nigeria, with its capital in Yola. Adamawa is one of the largest states in Nigeria and occupies about $36,917 \mathrm{~km}^{2}$. It is bordered by the states of Borno in the northwest, Gombe in the west and Taraba to the southwest. Its eastern border also forms the national eastern border with Cameroon. Topographically, it is a mountainous land caused by the large river valleys- Benue, Gongola and Yedsare. The valleys of Cameroon, Mandara and Adamawa mountains form part of the landscape. The State has an estimated population of $3,737,223$ (2005) and lies within the coordinates, $9^{\circ} 20^{\prime} \mathrm{N}$ and $12^{\circ} 30^{\prime} \mathrm{E}$.

Taraba state is a state in Nigeria, named after the Taraba River which traverses the southern part of the state. Taraba's capital is Jalingo and has 16 local government areas. The state is bounded in the west by Plateau and Benue states, on the east by the Cameroon and in the north by Adamawa state. The State has a landmass of 54,473 $\mathrm{km}^{2}$, has an estimated population of $2,688,944$ (2005) and lies within the coordinates, $8.00^{\prime} \mathrm{N}$ and $10^{\circ} 30^{\prime} \mathrm{E}$.

\section{Sampling/Data collection procedure}

Three stage sampling methods were used in the selection of respondents for the study. The first stage was the sampling of nine dairy producing Local Government Areas (LGAs) in Taraba state. Namely: Jalingo, Sardauna, Bali, Yorro, Ardo-kola, Gashaka, Karim lamido, Zing and Lau LGAs, while the 11 LGA in Adamawa state includes; Shelleng, Lamorde, Mayo-balwa, Numan, Toungo, Guyuk, Demsa, Gombi, Song, Jada and Ganye. The second stage was the purposive sampling of three dairy producing communities in each of the 20 LGAs. The third and final stage was the focus on identification of 10 persons in each dairy producing community for in-depth face-to-face interview.

\section{Data analysis}

Descriptive statistics and counts from multiple responses analysis were used to determine distributions and magnitudes of variables among the respondents.

\section{Results and discussion}

The results showed that most $\mathbf{( 8 2 . 0 \% )}$ of the respondents were male aged 30 years or more and majority $(78.0 \%)$ had no formal education. Majority of pastoralists $(\mathbf{8 4 . 2 \%})$ were married who practiced extensive grazing system and mostly (68.7\%) own Bunaji (White Fulani) breed of cattle. Majority $(63.3 \%)$ of the pastoralists were into dairy production for more than 10 years that grazed their animals on communal lands $(77.5 \%)$ and that $91.7 \%$ of them take their animals to the nearby rivers to drink (Table 1). Pastoral societies were dominated by men (Blench, 2001). That is male kept in trust even cattle owned by female members of the household. This 


\section{Adamu, Ardo and Aliyara}

may be for the fact that the Fulbe ethnic group is patrilineal by culture and the concentration of cattle is in the hands of male. Even in situation where female household members owned cattle, they did so by proxy (Edwin et al., 2018). In pastoral settlements, young boys begin to learn livestock responsibilities when they are as old as 10 years or older (Edwin et al., 2018, Morner, 2006). Their responsibility increases as they age. The high percentage of married respondents might be connected to the fact that since milk is a major source of income to the pastoral families (Asaminew, 2007). A study found that most full- time dairy production pastoralists' were illiterates (Millogo et al., 2018). The role of education is obvious in affecting household income, adopting technologies, demography, health, and as a whole the socio-economic status of the family as well (Kerealem, 2005). The fact that local breeds of cattle produce less amount of milk and the differences cattle breeds showed in milk composition and yield (10'Connor, 1994), Crossbreeding indigenous breed with grade animals can increase and improve milk production (Perera, 1999). Natural pasture, browse and bushes accounts for the major food sources for livestock owned by pastoralists (Ibrahim and Ololaku, 2000). A study showed that Pastoralists land use is based on customary traditions and they hold the land under communal tenure (MigotAdholla et al., 1991). The Maasai pastoralists also rely on seasonal rivers as source of water for their livestock (Edwin et al., 2018) as well as Pastoralists in Ethiopia (Kuma et al., 2015) and in Burkina Faso (Millogo et al., 2018). Majority of the pastoralists surveyed $(98.2 \%)$ sold raw milk once a day and $12.7 \%$ of the cattle in the study area produced up to three liters/day (Table 2). Most milk produced every day in the pastoral settlements, $81.5 \%$ was used for family and sales and $99.3 \%$ of pastoralists' calves were fed through suckling. There was slight difference between those that sold in one market $(57.8 \%)$ and those that patronized more than one market $(42.3 \%)$. Respondents that were willing to sell to milk collectors were $62.5 \%$.

In pastoral system, the major product is milk (Jahnke, 1982). In pastoral societies, the first and most important purpose of dairy cattle production are to provide milk for family use and for sale (Jahnke, 1982). Milk is a perishable product and processing must start immediately after milking (Ahmed et al., 2003). In pastoral communities, milk tends to be adequate for home consumption as well as for market (Beruk and Tafesse, 2000). However, in Ethiopia, about $2.6 \%$ of pastoralists in a survey used refrigerators to cool raw milk (Kuma et al., 2015). A study showed that average milk yield of indigenous breeds of cattle in Nigeria ranges between 0.7-1.5 litres/day (Annette, 2010) and 1-2 liters in Burkina Faso (Millogo et al, 2018), but stated that this could be higher if milk for the calf is included. However, in Ethiopia $97 \%$ of pastoralists in a survey produced raw milk in excess of 6 liters a day per cow (Kuma et al., 2015). Due to absence of basic infrastructure, marketing milk in any volume is restricted to the urban and peri urban areas (Getachew, 2003) and this can affect milk sales (IPS, 2000) because demand for milk is high in urban areas (Ahmed et al., 2003). Informal milk sale is characterized by no licensing, low cost of operation, high producer prices compared to formal market and no regulation of operation (Debrah and Berhanu, 1991). Formal markets on the other hand involves, milk collection and transportation in bulk from widely scattered rural sources require a well-defined method of preservation and distribution (Ahmed et al., 2003). Respondents indicated that sales were higher in the rainy season $(97.0 \%)$ and most 
Dairy production practices at pastoral settlements of Adamawa and Taraba states, Northeastern Nigeria

Table 1: Socio-demographic characteristics of respondents (\%)

\begin{tabular}{|c|c|c|c|c|}
\hline & & Taraba state $(\mathrm{N}=\mathbf{2 7 0})$ & $\begin{array}{l}\text { Adamawa state } \\
(\mathrm{N}=330)\end{array}$ & Combined $(\mathrm{N}=600)$ \\
\hline & Gender & & & \\
\hline 1) & Male & $208(77.4)$ & $284(86.1)$ & $492(82.0)$ \\
\hline \multirow[t]{2}{*}{ 2) } & Female & $62(22.6)$ & $46(13.9)$ & $108(18.0)$ \\
\hline & Age & & & \\
\hline 1) & $<30$ & $31(11.5)$ & $47(14.2)$ & $78(13.0)$ \\
\hline 2) & $31-40$ & $67(24.8)$ & $118(35.8)$ & $185(30.8)$ \\
\hline 3) & $41-50$ & $111(41.1)$ & $101(30.6)$ & $212(35.3)$ \\
\hline \multirow[t]{2}{*}{ 4) } & $>50$ & $61(22.6)$ & $64(19.4)$ & $125(20.8)$ \\
\hline & Marital status & & & \\
\hline 1) & Single & $33(12.2)$ & $18(5.5)$ & $51(8.5)$ \\
\hline 2) & Married & $223(82.6)$ & $282(85.5)$ & $505(84.2)$ \\
\hline 3) & Divorce & $0(0.0)$ & $10(3.0)$ & $10(1.7)$ \\
\hline \multirow[t]{2}{*}{ 4) } & Widowed & $14(5.2)$ & $20(6.0)$ & $34(5.7)$ \\
\hline & Educational Level & & & \\
\hline 1) & None & $223(82.6)$ & $245(74.3)$ & $468(78.0)$ \\
\hline 2) & Primary & $19(7.0)$ & $35(10.6)$ & $54(9.0)$ \\
\hline 3) & Secondary & $10(3.7)$ & $39(11.8)$ & $49(8.2)$ \\
\hline \multirow[t]{2}{*}{ 4) } & Higher & $18(6.7)$ & $11(3.3)$ & $29(4.8)$ \\
\hline & Livestock ownership & & & \\
\hline 1) & Yes & $228(84.4)$ & $283(85.8)$ & $511(85.2)$ \\
\hline \multirow[t]{7}{*}{ 2) } & No & $42(15.6)$ & $47(14.2)$ & $89(14.8)$ \\
\hline & Business period (yrs) & & & \\
\hline & $<3$ & $7(2.6)$ & $22(6.7)$ & $29(4.8)$ \\
\hline & $4-6$ & $34(12.6)$ & $29(8.8)$ & $63(10.5)$ \\
\hline & $7-9$ & $73(27.0)$ & $55(16.7)$ & $128(21.3)$ \\
\hline & $>10$ & $156(57.8)$ & $224(67.9)$ & $380(63.3)$ \\
\hline & Breed of cattle & & & \\
\hline 1) & White Fulani & $199(73.3)$ & $213(64.5)$ & $412(68.7)$ \\
\hline 2) & Red Bororo & $35(13.0)$ & $59(17.9)$ & $94(15.70$ \\
\hline 3) & Bokoloji & $36(13.30$ & $40(12.10$ & $76(12.7)$ \\
\hline \multirow[t]{2}{*}{ 4) } & others & $0(0.0)$ & 1895.5) & $18(3.0)$ \\
\hline & $\begin{array}{l}\text { Grazing land } \\
\text { ownership }\end{array}$ & & & \\
\hline 1) & Yes & $48(17.8)$ & $87(26.40$ & $135(22.5)$ \\
\hline \multirow{2}{*}{ 2) } & No & $222(82.20$ & $243(73.6)$ & $465(77.5)$ \\
\hline & Source of water & & & \\
\hline 1) & River & $264(97.5)$ & $286(86.7)$ & $550(91.7)$ \\
\hline 2) & Lake & $4(1.5)$ & $10(3.0)$ & $14(2.3)$ \\
\hline 3) & Borehole & $0(0.0)$ & $24(7.30$ & $24(4.9)$ \\
\hline 4) & others & $2(0.7)$ & $10(3.0)$ & $12(2.00$ \\
\hline
\end{tabular}

$(89.2 \%)$ respondents' reported lack of visits by extension agents (Table 3 ). There was awareness $(60.7 \%)$ that banks give loans for dairy business, but $91.8 \%$ of the respondents never used any bank facility. Majority $(82.7 \%)$ of the respondents were not members of any milk producing cooperative society, however, most $(96.6 \%)$ of them indicated they are willing to join a milk production cooperative

society.

Milk sales are seasonal in pastoral and agro-pastoral dairy production systems (Zegeye, 2003; Annette and Ilu, 2016). The seasonality of milk availability is because the capacity for high level of production in the dry season by the indigenous breeds has remained low (IPS, 2000). The absence of dairy extension services will play a negative role in production and efficiency 
Adamu, Ardo and Aliyara

Table 2: Milk marketing practices by respondents (\%)

\begin{tabular}{|c|c|c|c|c|}
\hline & & $\begin{array}{l}\text { Taraba } \\
\text { state }(N=2700)\end{array}$ & $\begin{array}{l}\text { Adamawa } \\
\text { state }(N=330)\end{array}$ & Combined $(\mathrm{N}=600)$ \\
\hline & \multicolumn{4}{|l|}{ Raw milk sales/day } \\
\hline$)$ & Once & $266(98.5)$ & $323(97.9)$ & $589(98.2)$ \\
\hline ) & Twice & 491.50 & $7(2.1)$ & $11(1.8)$ \\
\hline ) & Thrice & $0(0.0)$ & $0(0.0)$ & $0(0.0)$ \\
\hline & \multicolumn{4}{|l|}{ Production/animal/day(L) } \\
\hline & $<1$ & $84(31.1)$ & $79(23.9)$ & $163(27.2)$ \\
\hline & $2-3$ & $148(54.8)$ & $183(55.5)$ & $33(55.2)$ \\
\hline & $>3$ & $38(14.10)$ & $38(11.5)$ & $76(12.7)$ \\
\hline & \multicolumn{4}{|l|}{ Usage of milk } \\
\hline ) & Family only & $11(4.1)$ & $55(16.7)$ & $66(11.0)$ \\
\hline ) & Sale only & $11(4.1)$ & $43(10.3)$ & $45(7.5)$ \\
\hline ) & \multicolumn{4}{|l|}{ Calves feeding } \\
\hline$)$ & Bucket & $0(0.0)$ & $4(1.2)$ & $4(0.70$ \\
\hline ) & Suckling & $270(100.0)$ & $326(98.8)$ & $596(99.3)$ \\
\hline & \multicolumn{4}{|l|}{ Milk transport to market } \\
\hline$)$ & Truck & $82(30.4)$ & $250(75.8)$ & $332(55.3)$ \\
\hline ) & Foot & $188(69.6)$ & $80(24.2)$ & $268(44.7)$ \\
\hline & \multicolumn{4}{|l|}{ Point of sales(markets) } \\
\hline ) & One & $190(70.30$ & $157(47.6)$ & $347(57.8)$ \\
\hline ) & More & $80(29.7)$ & $173(52.4)$ & $253(42.3)$ \\
\hline & \multicolumn{4}{|l|}{ Milk sale to collectors } \\
\hline ) & Yes & $236(87.4)$ & $139(42.1)$ & $375(62.5)$ \\
\hline 2) & No & $34(12.6)$ & 191(57.9) & $225(37.5)$ \\
\hline
\end{tabular}

Table 3: Constraints and challenges in milk production by respondents (\%)

Taraba state $(\mathrm{N}=270) \quad$ Adamawa state $\quad$ Combined $(\mathrm{N}=600)$ $(\mathbf{N}=330)$

\begin{tabular}{llll}
\hline $\begin{array}{l}\text { Seasonality of sales } \\
\text { Rainy season }\end{array}$ & $270(100)$ & $320(96.97)$ & $590(98.3)$ \\
$\begin{array}{l}\text { Dry season } \\
\text { Extension visits }\end{array}$ & $0(0.0)$ & $10(3.03)$ & $10(1.7)$ \\
Yes & $2(0.7)$ & $63(19.1)$ & $63(10.8)$ \\
No & $268(99.3)$ & $267(80.9)$ & $537(89.2)$ \\
Knowledge of bank & & & \\
loans & & $234(70.9)$ & $236(39.3)$ \\
Yes & $2(0.7)$ & $96(29.1)$ & $364(60.7)$ \\
No & $268(99.3)$ & & \\
Any benefit from & & $48(14.5)$ & $49(8.2)$ \\
bank loans & & $286(85.5)$ & $551(91.8)$ \\
Yes & $1(0.4)$ & & \\
No & $269(99.6)$ & $88(26.7)$ & $104(17.3)$ \\
Membership of & & $242(73.3)$ & $496(82.7)$ \\
cooperative societies & & & \\
Yes & $16(5.9)$ & $232(70.3)$ & $479(96.6)$ \\
No & $254(94.1)$ & $10(29.7)$ & $17(3.4)$ \\
If No, willingness to & & & \\
join one & & & \\
Yes & $247(97.2)$ & & \\
No & $7(2.8)$ & & \\
\hline
\end{tabular}


of the dairy industry in Nigeria (Annette and Ilu, 2016). A situation that might cause pastoral societies to feel been marginalized by government policies and development strategies (Dong, 2016). Finance is very important factor in dairy production expansion, so that credit is one of the sources to finance the dairy. Business models that incorporate cooperatives or community associations are given technical assistance by the government (Annette and Ilu, 2016). In commercial dairy production, the private sector is expected to take the lead to be involved in the business transaction. Cooperative societies assist pastoralists sell in bulk, collective bargaining, and increase market access and to avoid hazards of being encumbered with a perishable product with no rural demand (Annette and Ilu, 2016). In spite of challenges, however, in China, modernizing traditional pastoral activities is currently challenging the sustainable development of pastoralism (Kreutzman, 2013), by promoting the urbanization of township development in pastoral areas.

\section{Conclusion and applications}

In conclusion, to improve the dairy industry requires a higher literacy level among pastoralists, through mass literacy programs. There is need for Government to address absence of basic infrastructure, lack of extension agents to exploit the potentials of business skills of pastoralists.

\section{References}

Ahmed, I. 2003. Breed effect on production in Egypt. Journal of Animal Sciences. 12.45-49.

Annette, I. 2010. Nigeria- milk production fact sheet. In ; IFCN dairy report 2009 International Farm Comparison Network, Dairy Research Center, Kiel ,Germany. 3(63). 129.

Annette, I. and Ilu, I. Y. F. 2016. Review of the livestock/meat and milk value chains and policy influencing them in Nigeria. FAO/UN/ECOWAS. $1-48$.

Asaminew, T. 2007.Production, handling, traditional processing practices and quality of milk in Bahir Dar milk shed Area, Ethiopia. M.Sc. Thesis. Alemaya University, Ethiopia.

B e ruk, Y. a nd Tafesse, M . 2000.Pastoralism and agropastoralism: past and present. In: Proceeding of the 8th Annual conference of ESAP (Ethiopian Society ofAnimal Production). Addis Ababa Ethiopia. 54-58.

Blench, R. 2001. You can't go home again: Pastoralism in the new millenium. Overseas Development Institute (ODI), London, UK.

David, B., Nick. M. and John, M. 2001. Drought, Losses, Pastoral Saving and Banking: A Review. DFID Advisory Support Services Commission Project. United Kingdom.

Debrah, S. and Berhanu, A. 1991. Dairy marketing in Ethiopia: Markets of first sale and producers' marketing patterns. ILCA Research Report. (19). Addis Ababa, Ethiopia.

Delgado, C., Rosegrant, M., Steinfield, H., Ehui, S. and Courbois, C. 1999. Livestock to 2020: the next food revolution. Food, Agriculture, and the Environment discussion Paper 28. Washington, DC: International Food Policy Research Institute (IFPRI), Food and Agriculture Organization (FAO) and International Livestock Research Institute (ILRI). 83.

Dong, S. 2016. Overview. Pastoralism in the world. Springer International Publishing,Switzerland. 1-38.

Edwin, A. A., Atieno, B. S., Owuor O. C., 
Haller, T., Wandibba, S. and Nangendo, S. 2018. Pastoral Resilience among the Maasai Pastoralists of Laikipia County, Kenya. Land,7.1-17

Food and Agriculture Organization (FAO) and International Dairy Federation (IDF) 2004. Dairy Development Newsletter. October Issue (8).

Getachew F. 2003. A Review of the small scale milk sector in Ethiopia. FAO. Ethiopia.

Ibrahim, H. and Olaloku, E. 2000. Improving cattle for milk, meat and traction. ILRI, manual 4. ILRI (International Livestock Research Institute), Nairobi, Kenya.

IPS (International Project Service) 2000. Resource potential assessment and project identification study of the Somalia Region: Research Report. Vol.III. Somalia, Ethiopia.

Jahnke, H. E. 1982. Livestock production systems and livestock production in Tropical Africa. Kieler Wissensch. VerlagVauk, Kiel. Germany. 273.

Kerealem, E. 2005. Honeybee production systems, opportunities and challenges in enebs Esarmidirwereda (Amhara region) and Amaro Special Wereda (Southern Nations, Nationalities and Peoples Region), Ethiopia. M.Sc. Thesis, Alemaya University, Ethiopia.

Kuma, A., Tolossa, D. and Abdisa, M. 2015. Evaluation of proximate composition and handling practices of raw milk at different points of Oromia regional state. Food Science and Quality Management. 39.31-40.

Kreutzmann, H. 2013. The tragedy of responsibility in high Asia: modernizing traditional pastoral practices and preserving modernist worldviews. Pastoralism. 3.7 http://www.pastoralismjournal. com $/$ content $/ 3 / 1 / 7$

Magembe, E. M., Bebe, B. O. and Legat, K. 2014. How are pastoral households economic benefits compared to agro-pastoralist benefits in Transmana West district of Narok county, Kenya. Sky Journal of Agricultural Research. 3(2). 53-61.

Migot-Adholla, S., Hazell, P. and Blarel, B. 1991.Indigeneous land rights system in sub-saharan Africa; a constraint on productivity? The World bank Economic Review. 5. 155.

Millogo, V., Ouedrago, G. A., Agnes, S. and Svernnenten-Sjaunja, $K$. 2008. Survey on dairycattle milk production and milk quality problems in peri-urban areas in Burkina Faso. African Journal of Agricultural Research. 3(3). 215224.

Morner, S. 2006. The Maasai: Changes in Livelihood after Land Loss. Bachelor's Thesis, Sodertorn. University College Press, Sodertorn. Sweden.

Mpairwe, D. 2001. Under Nutrition in Diary Ruminants and Intervention Options for Coping with Feed Scarcity. Smallholder Production Systems in Uganda. 19.67-71.

O'Connor, C. B. 1994. Rural dairy technology. International Livestock Research Institute (ILRI) training manual No. 1. Addis Ababa, Ethiopia.

Oni, O. O., Adeyinka, I. A., Afolayan, R. A., Nwagu, B. I., Malau-Aduli, A. E. O., Alawa, C. B. I. and L a m i d i , O . S . 2001 . Relationships between milk yield, 
Dairy production practices at pastoral settlements of Adamawa and Taraba states, Northeastern Nigeria

post-partum body weight and reproductive performance in Friesian x Bunaji cattle. Asian-Australian Journal of $\begin{array}{llllll}A & n & i & m & a & l\end{array}$ Science.14(11).1516-1519.

Perera, O. 1999. Management of reproduction. ILRI (International Livestock Research Institute), Nairobi. Kenya.

The World Bank. 2008. Agriculture for Development: World Development Report 2008. Washington, DC: The World Bank.
Walshe, M. J., Grindle, J., Nell, A. and Bachman, M. 1991. Dairy Development in Sub-Saharan Africa - A Study of Issues and Options. Technical Paper No. 135, Africa Technical Development Series. The World Bank, Washington $D C$.

Zegeye, Y. 2003. Challenges and opportunities of livestock marketing in Ethiopia. In: Proceeding of the 10th Annual Conference of Ethiopian Society of Animal Production (ESAP), Addis Ababa. Ethiopia

Received: $19^{\text {th }}$ September, 2019 Accepted: $24^{\text {th }}$ February, 2020 